Discussion Paper No. 04-78

\title{
Is Silence Golden?
}

\section{Patents versus Secrecy at the Firm Level}

\author{
Katrin Hussinger
}

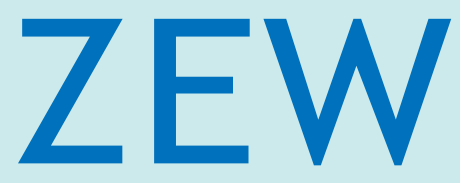

Zentrum für Europäische Wirtschaftsforschung $\mathrm{GmbH}$

Centre for European

Economic Research 
Discussion Paper No. 04-78

\section{Is Silence Golden? \\ Patents versus Secrecy at the Firm Level}

Katrin Hussinger

Download this ZEW Discussion Paper from our ftp server:

ftp://ftp.zew.de/pub/zew-docs/dp/dp0478.pdf

Die Discussion Papers dienen einer möglichst schnellen Verbreitung von neueren Forschungsarbeiten des ZEW. Die Beiträge liegen in alleiniger Verantwortung der Autoren und stellen nicht notwendigerweise die Meinung des ZEW dar.

Discussion Papers are intended to make results of ZEW research promptly available to other economists in order to encourage discussion and suggestions for revisions. The authors are solely responsible for the contents which do not necessarily represent the opinion of the ZEW. 


\section{Non-Technical Summary}

During the 1990s, patenting schemes changed in many respects: technological and institutional conditions altered, upcoming new technologies accelerated the shift from price competition towards competition based on technological inventions, and the significance of strategic patenting increased. At the same time, a drastic surge in patent applications took place. These developments call for an investigation of patents' importance for intellectual property (IP) protection in subsequent years. In the context of the patent surge that was not accompanied by a comparable surge in research and development (R\&D) expenditure, patents may rather indicate strategic behavior of firms, while alternatives like secrecy - that has been found the more effective means of IP protection by previous empirical research focusing on the early 1990s - may be used for IP protection.

Patenting is a legal instrument for the protection of IP by granting the patent holder a temporary monopoly on the patented technology including the right to sue for infringement. However, patents bear the disadvantage that the patented technology has to be disclosed in order to show the court and competitors what is protected. This disclosure requirement uncovers profitable technology fields and, moreover, patent data bases, open to the public, allow an easy access to the patented knowledge. Thus, patenting conditions might enable and even encourage rival firms to invent 'around' a patented innovation. In order to avoid this, firms may prefer to keep their inventions secret instead.

Previous research on IP protection methods focusing on the early 1990s when the surge in patenting was still pending found that secrecy is the more effective means of IP protection as opposed to patents (Arundel, 2001, and König and Licht, 1995). Those studies focus on the firms' evaluation of the respective IP protection methods to investigate their efficiency. In contrast, this study is interested in the protected inventions' success in the market to measure the importance of patents as opposed to secrecy perhaps more objectively. The disclosure requirement of patenting makes patents and secrecy mutually exclusive alternatives once an invention has entered the market. Thus, this study introduces the sales figure with new products as a new measure of the importance of IP tools among products innovating firms. 
The focus is on product innovating firms in German manufacturing in 2000. The Mannheim Innovation Panel (MIP) and patent information from the German Patent and Trademark Office constitute the data base. In 2000, the MIP identifies firms that use patents and firms that use secrecy as a means of protecting their IP. The importance of patents and secrecy is proxied by the protected inventions' success in the market, which is ultimately reflected in figures of sales with new products. Using tobit and instrumental variables regression a significant positive correlation between patenting and sales with new products turns out, whereas there is no effect for secrecy.

This finding is in line with the hypothesis that for product innovating firms patenting is the more important method to protecting inventions in their market phase as opposed to secrecy, even though over the recent years a more strategic use of patenting has gained in importance. This result is confirmed by survey evidence in the same year suggesting that patents are more important than secrecy to protect IP from the firms' point of view. The frequent use of secrecy may be explained by its protective value for early-stage inventions. 


\title{
Is Silence Golden? \\ Patents versus Secrecy at the Firm Level
}

\author{
Katrin Hussinger
}

November 2004

\begin{abstract}
In the 1990s, patenting schemes changed in many respects: upcoming new technologies accelerated the shift from price competition towards competition based on technical inventions, a worldwide surge in patenting took place, and the 'patent thicket' arose as a consequence of strategic patenting. This study analyzes the importance of patenting versus secrecy as an effective alternative to protect intellectual property in the inventions' market phase. The sales figure with new products is introduced as a new measure for the importance of IP protection tools among product innovating firms. Focusing on the German manufacturing in 2000, it turns out that patents are important to protect intellectual property in the market, whereas secrecy seems to be rather important for early-stage inventions.
\end{abstract}

Keywords: Innovation, Appropriation, Patents, Secrecy JEL-Classification: C34, C35, O33, O34

Address: Centre for European Economic Research (ZEW)

Department of Industrial Economics

and International Management

P.O.Box 103443

68304 Mannheim

Germany

Phone: $\quad+49 / 621 / 1235-381$

Fax: $\quad+49 / 621 / 1235-170$

E-Mail: hussinger@zew.de

I would like to credit Iain Cockburn, Dirk Czarnitzki, Paul A. David, Raol A. Gonzales, Diana Heger and Georg Licht for helpful comments, as well as York Besser and Christian Richter for data processing and Michael Hussinger for proofreading. Part of this paper was written during a research stay at the UC Berkeley granted by the German Academic Exchange Service (DAAD). I thank the UCB for hospitality as well as the DAAD for financial support. Moreover, financial support from the German Science Foundation (DFG) under the grant SFB/TR 15-04 is gratefully acknowledged. 


\section{Introduction}

During the 1990s, important changes in patenting schemes took place: technological and institutional conditions altered, upcoming new technologies accelerated the shift from price competition towards competition based on technological inventions, and strategic patenting gained in importance. At the same time, a drastic surge in patenting took place. These developments call for an investigation of the importance of patenting for the protection of intellectual property (IP). Since the patenting boom was not accompanied by a comparable increase in research and development $(\mathrm{R} \& \mathrm{D})$ expenditure, patenting may rather indicate strategic firm behavior, while alternatives like keeping a newly developed technology secret may be used for IP protection. This paper analyzes the importance of patents and secrecy to protect inventions in their market phase focusing on a sample of product innovating firms in German manufacturing in 2000.

The patent system counteracts incentive problems arising from the publicgood character of IP. Knowledge is non-exclusive and non-rival. Competitors may absorb, use and profit from knowledge without having to compensate the inventor firm. Thus, the social benefit of knowledge is larger than the private benefit and cannot be internalized by the inventor firm. Moreover, private costs of creating knowledge may exceed private benefits, which generates an incentive problem in producing IP. From a social point of view, this leads to an underinvestment in an economy's knowledge production. A patent is an instrument to overcome this incentive problem by granting its owner the right to sue for infringement in case someone makes use of the protected technology. In other words, a patent is a legal means of giving the patent holder a temporary monopoly on the protected IP.

However, to file a patent bears the disadvantage that the patented technology has to be disclosed so that competitors and the court know, what is protected. The disclosure requirement generates the patent holder some disutilities that might outweigh the monopoly benefits. First, a patent hints at a presumably profitable technology field. This enables competitors to jump on to a technological trend by conducting further research related to the patented technology. Second, publicly available patent information facilitates reverse engineering of an invention and may, thus, encourage a larger number of rival firms to invent around a patent.

Due to the disadvantages of the disclosure requirement in connection with significant patent application costs and potential infringement costs - which might be even higher than the application costs -, some firms may prefer keeping their invention secret instead of filing a patent. IP protection by 
secrecy is, of course, free of charge, but has the disadvantage that the invention is not legally protected against imitation or even duplication in case the secret is leaked. Therefore, the firms' decision to patent or to keep an invention secret is considered a trade-off between the temporary monopoly position a patent offers and the information spread a patent leads to.

Empirical studies focusing on the early 1990s, when the surge in patenting was still pending, conclude that firms prefer secrecy over patenting to protect their IP (e.g. Levin et al., 1987) and also that firms retrospectively consider secrecy more effective than patenting (Arundel, 2001). However, significant developments in the recent past concerning institutional and technological conditions of patenting as well as the increased strategic value of patents have evidently made patenting more attractive than it was before, as the worldwide patent surge indicates.

Most drastic institutional changes took place in the US during the 1980s, such as the Bayh-Dole act and the establishment of the Court of Appeal for the Federal Circuit that strengthens the patent holders' rights. Those developments pioneered for the pro-patent environment that gradually emerged and ultimately spread far beyond US borders. However, institutional changes in Europe were not overly drastic. The appropriation of IP has gained in importance for Europe because of the endeavors of international harmonization of the patent law, but also for reasons of competitiveness. Today, the decline in competitiveness of European firms is partly seen as a consequence of their patent behavior, which has been much less aggressive than in other patent nations (Arundel, 2001). The European Commission reacted with the Green Paper on Innovation, which puts application and defense costs as important barrier's for patenting up for discussion, and the First Action Plan for Innovation in Europe, which encourages European firms, especially small and medium sized firms (SMEs), to patent more. Furthermore, patent application costs were lowered and grace periods have been fiercely discussed 11 In addition, initiatives were promoted to support SMEs, and specifically hightechnology SMEs, with information and patenting programs.

Those institutional developments aimed at making patenting more attractive. However, empirical studies for the US, where the institutional changes were more drastic, have shown that those changes cannot explain the recent increase in patenting. Reasons for the surge in patenting can rather be found in changes in firms' R\&D management and reallocations of their R\&D port-

\footnotetext{
${ }^{1}$ Grace periods would permit the release of information about an invention without loosing the right to apply for a patent at a later time, e.g. when a mechanical invention requires external testing under the participation of another firm.
} 
folios (Kortum and Lerner, 1999) as well as in strategically motivated patent races and in an improved patenting management of the firms (Hall and Ham, 2001, for the semiconductor industry).

Upcoming new technologies, like biotechnology and information technology, as well as progresses in the information and communication technology caused the changes in technological conditions and, further, accelerated the shift from price competition towards competition based on technical inventions. These developments may have led to an increased need for patents providing legal IP protection in the face of a fiercer technological competition.

However, the strategic value of patents gained importance as well. Patents became an important tool in licensing as well as in merger and acquisition negotiations. The fact that patents, further, may increase firm value, generate profits from licensing, and serve as positive signals to potential investors became important, especially in the context of an increased number of small high-technology firms. Those firm often lack market power and the capability to transfer every idea into a new product. For them, patenting is a way of profiting from their inventions at least to a certain degree (Arundel, 2001). A further development is that patents gained in value by their ability to be linked with other patents, which encourages patenting of marginal inventions. The resulting complex network of single patents that bears many legal pitfalls for patent applicants was given the name 'patent thicket' (Shapiro, 2001). These developments put into question an increased number of patents motivated by an increased need for IP protection and hint at the strategic value of patents to have driven the patent surge.

To summarize: on the one hand, recent changes in patenting schemes have caused an elevated need for patents as an IP protection tool. On the other hand, they gained in importance as strategic instruments.

A look at the development of $R \& D$ expenditure as the presumably most important input factor for knowledge production provides a further argument for the hypothesis that the increase in patents rather is motivated by their elevated strategic value. The rising number of patent applications at the German Patent and Trade Mark Office (GPTO) over time stresses the patent surge in the 1990s for German firms. Figure 1 shows a continuous increase in patent applications at the GPTO during the 1990s, whereas before and after this period the number of filings is relatively constant. With a national share of $83 \%$, Germany was the largest applicant country at the GPTO in 2000. Germany is of considerable interest in the context of European patent policy being the largest European patent applicant at the European Patent 
Figure 1: Filings at the GPTO

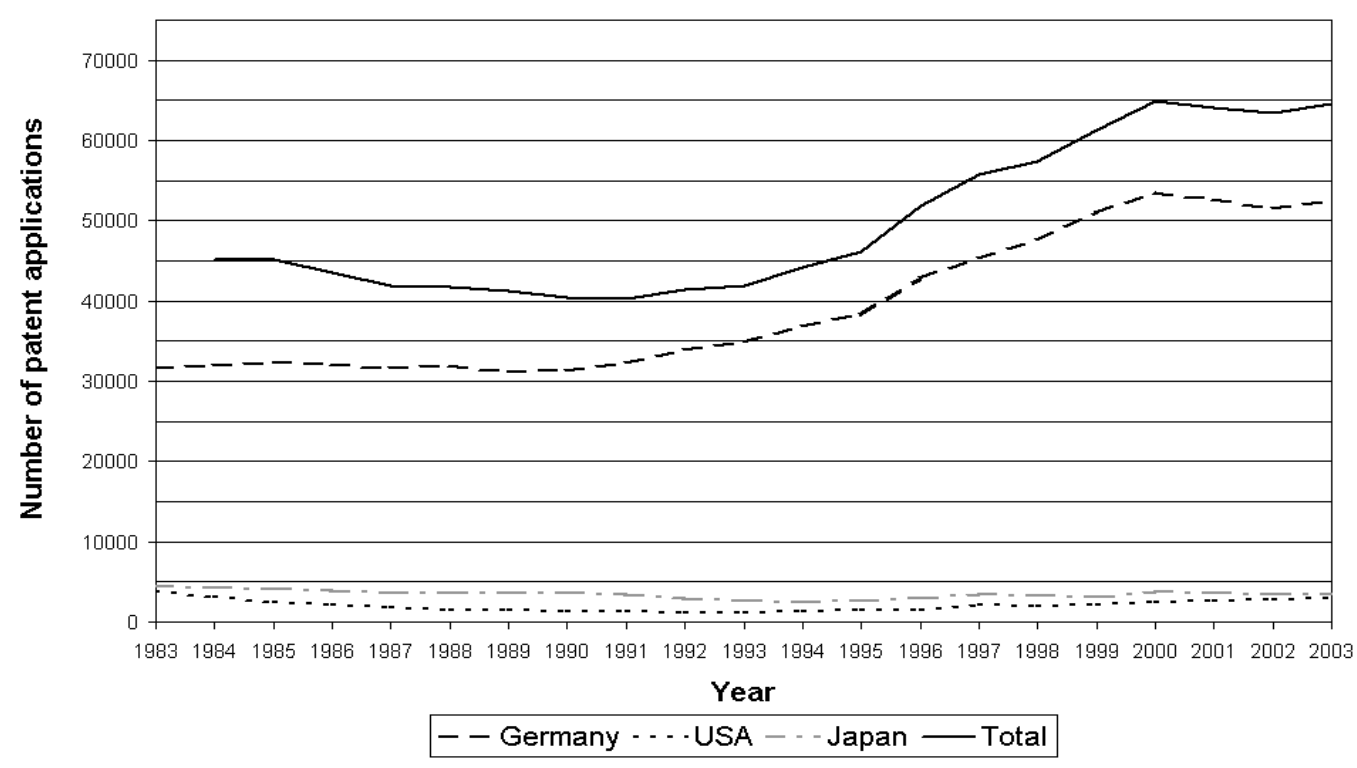

Office (EPO) with about 20,000 filings in 20002

In between 1990 and 2000, Germany's patent applications grew by about $71 \%$ at the GPTO and at a similar rate of $68 \%$ at the EPO. In the same time frame, Germany's R\&D expenditure grew by about $41 \%$ only $!^{3}$ Since this disproportionateness of patent applications and the presumably most important production factor for knowledge can only partially be explained by technological progress, it raises questions regarding the importance of patenting for IP protection. Does patenting rather indicate strategic firm behavior while IP is better protected by secrecy?

This paper investigates the importance of patents and secrecy after the 1990s' significant changes in patenting schemes took place. As previous studies focus on the firms' evaluation of the different IP tools to measure their importance, this study introduces the inventions' market success as a new measure of the importance of patents as opposed to secrecy for product innovating firms. The importance of inventions protected by patents and such protected by secrecy is distinguishable in the market phase, because patents and secrecy

\footnotetext{
${ }^{2}$ Patent data is taken from various annual reports of the GPTO. Patent applications are defined as direct applications and Patent Cooperation Treaty applications in the national or regional phase with effects in the Federal Republic of Germany. Note that German filings with the EPO are included in the GPTO data with a one-year lag caused by priority.

${ }^{3}$ Information on R\&D expenditure is taken from the Stifterverband (2003/04).
} 
are mutually exclusive for the particular invention once the invention has entered the market. Inventions' market success is measured by the sales figure with new products. The focus is on product innovating firms in German manufacturing in 2000 .

The remainder of the paper is as follows: section 2 summarizes the recent literature, section 3 provides information on the data and descriptive statistics, section 4 discusses the estimation results and section 5 concludes.

\section{Literature Review}

The literature on IP appropriation mechanisms was long time dominated by the statement of Friedman et al. (1991) according to which no rational individual with a patentable invention would fail to patent it. This attitude was reflected in theoretical model assumptions without leaving any room for alternative instruments of IP protection. ${ }^{4}$ The underlying economic background is the temporary monopoly a patent grants, which allows firms to secure monopoly profits by protecting patented IP against undesired adaption by competitors for a certain period of time. Thus, patents generate incentives to innovate. The central problem discussed in the theoretical literature is the trade-off between the inefficiency of the monopoly and the incentives to innovate 5

Mansfield (1986) empirically analyzes the relationship between patenting and innovation behavior within a random sample of 100 US manufacturing firms. He finds that a substantial fraction of patentable inventions is not patented. He further highlights large differences among industries. In some industry sectors, like the pharmaceutical or chemical industry, the effectiveness of the patent system is found to be substantial, and accordingly a large share of the patentable inventions, about $80 \%$, is patented. In other industries, patents appear to be relatively unimportant. In the motor vehicle industry, e.g., the share of patented invention is only about 60\%. Mansfield (1986) concludes that "clearly, firms generally do not prefer to rely on trade secrecy protection when patent protection is possible".

A few theoretical papers focus on secrecy as an alternative IP protection tool

\footnotetext{
${ }^{4}$ See e.g. Tandon (1982) or Scotchmer (1991) for theoretical models basing on such assumptions. Scotchmer (2004) provides a more balanced view.

${ }^{5}$ Seminal studies are provided by Nordhaus $(1969,1972)$. Denicolò (1996) and Langinier and Moschini (2002) provide surveys on this theoretical literature.
} 
(Horstman et al., 1985, and Anton and Yao, 2004)6 Analyzing the choice to patent or to keep an invention secret, Anton and Yao (2004) point out three important features for understanding the management of IP: first, the incomplete information about the extent of an innovation, second, the limitedness of IP protection, and third, the fact that imitation is facilitated by disclosure. Horstman et al. (1985) and Anton and Yao (2004) develop information signaling models on the decision to patent or to keep an invention secret with respect to strategic aspects.

The fact that neither patents - neither appropriability in the monopoly situation is perfect nor diffusion through public disclosure is ultimate after the patent expires - nor secrecy, which may leak out, perfectly work as theory suggests brought up a demand for empirical investigation.

Levin et al. (1987) pioneer the field with the so-called Yale I study, in which they analyze survey data on firms' appropriation activities in US manufacturing. They find that patents are not the most important mechanism of IP appropriation. Secrecy, learning advantages as well as sales and service efforts are more important. Furthermore, they detect significant inter-industry variation regarding the use of IP protection instruments. In chemical and pharmaceutical industry, patents are most often used and are considered to be more effective than in other industry sectors. A further result is that product innovations are better suited to patent protection than are process innovations.

Cohen et al. (2000) add a consecutive study (Carnegy Mellon survey) for US manufacturing. Their findings confirm the results by Levin et al. (1987): according to them patents are the least emphasized instrument of IP protection (compared to secrecy, lead time advantages, and the use of complementarity marketing and manufacturing capabilities) for the majority of the sampled firms. They further point out that the reason behind patenting in general is not IP protection but strategic arguments, like bargaining power, crosslicensing, and reputation. In addition, their results underline the significance of industry differences, separating industries that usually introduce a 'discrete' product (e.g. a new substance in chemical industry) from industries that usually develop 'complex' products (e.g. a new product in the electronic sector). Cohen et al. (2000) show that most patents are filed by the chemical and pharmaceutical industry, and further that product innovations are better suited to patent protection than process innovations. These results confirm the findings of Levin et al. (1987).

\footnotetext{
${ }^{6}$ This list does not claim to be complete.
} 
The PACE report (Arundel et al., 1995) as the European counterpart of the Carnegy Mellon survey focuses on the European Union's 840 largest manufacturing and industrial firms located in Germany, the UK, Italy, Belgium, the Netherlands, Luxembourg, Spain, Denmark, and France. The findings of the PACE report countersign important industry variations regarding the effectiveness of IP protection tools for European firms. For Europe as for the US, patents play an outstanding role in the pharmaceutical and chemical industry for both, product and process inventions. Arundel et al. (1995), further, find that patents and lead-time advantages are most important to protect process inventions, whereas secrecy is most important to protect process inventions in most industries. Moreover, Arundel et al. (1995) report differences regarding the importance of IP protection methods among EU countries. German firms, in general, consider a range of IP protection tools effective compared to the other EU countries. Consequently, Germany shows the highest patent rate.

In 1992, the Community Innovation Survey (CIS) of the European Commission starts dealing with questions on IP protection. Unlike the PACE study that focuses on the largest European firms, the CIS takes SMEs into account. The CIS I wave (1992) asked the firms to evaluate several legal and non-legal methods of IP protection with regard to product and process innovations separately. Respondents score the importance of the different IP protection tools on a five-point likkert scale. Only few studies analyze this information. Arundel (2001) focuses on the relative effectiveness of patents and secrecy using the CIS I survey for six EU countries. He estimates ordered logit models on the relative efficiency of patents and secrecy. This approach has the advantage that it takes into account unobserved firm heterogeneity. Arundel (2001) concludes that secrecy provides an effective alternative for IP protection. Moreover, he finds that firms rate secrecy even more effective than patents independent of firm size.

König and Licht (1995) investigate the importance of patents compared to different non-legal IP protection methods using the CIS I wave for the German manufacturing. Their results confirm the findings by Levin et al. (1987) that non-legal IP protection instruments are more effective than the legal tools. In contrast to the finding of Yale I, the study on Germany finds every non-legal IP protection tool more effective for protection of product innovations than patents. They further conclude that highly innovative firms rather rely on a bundle of IP rights than on patents only. Further, the results for Germany contrast with Arundel's (2001) analysis for several European countries by stating that patents are more important for larger firms than for 
SMEs.

A drawback of the CIS I wave is that the firms are asked to evaluate the different IP protection tools regardless as to whether they have ever used the specific tools. Thus, the rating by firms that have never used patents or secrecy gets the same weight as the scoring by experienced firms. The CIS III wave, in contrast, asks the firms, which IP protection methods they have used, and enables rating only to those firms that have actually used the IP protection tool. Unfortunately, the questions in CIS I and CIS III differ by such a high degree that a comparative analysis is impossible.

Hanel (2002) analyzes the use of IP protection for the Canadian manufacturing, paying attention to a possible effect on profits. As a first step, he focuses on the propensity of innovative firms to protect their IP. He affirms Mansfield's (1986) results for Canada, which state that although firms do not trust in the protective effect of those instruments, most of them use at least one of them to protect their IP. Small firms are using IP protection tools less often and world-first inventors use every kind of IP protection more frequently than other firms. The Canadian survey provides information on the impact of IP protection on profits. Firms rated this effect on a five-point likkert scale. The scoring, however, is not related to particular IP protection instruments. Hanel (2002) finds that firms, which protect their IP, state that IP protection increased or maintained their profit.

This study analyzes the importance of patents and secrecy in terms of inventions' success in the market on the firm level using the CIS III survey data. This data base allows me to identify the firms that have actually applied the particular protection tools, which is a clear advantage compared to the CIS I wave. Going beyond an investigation of the relationship between the use of different IP protection tools by particular firms, this study analyzes the relationship of patents, secrecy, and sales with new products. The effectiveness of different IP protection tools is measured in terms of the protected inventions' market success at the firm level. Are the most promising inventions protected by patents or is it rather true that silence is golden?

\section{$3 \quad$ Data and Descriptive Statistics}

The underlying data base is the Mannheim Innovation Panel (MIP), a survey conducted yearly by the Centre for European Economic Research (ZEW) on behalf of the Federal Ministry of Education and Research (BMBF) since 1992. With its focus on the firms' innovation behavior, the MIP is the 
German part of the Community Innovation Survey (CIS) of the European Commission. The CIS survey is conducted every fourth year, so far in 1992, 1996, and 2000. This paper bases on the CIS III wave that poses the question, what IP protection tools the firms have used during the past three years. In addition, patent information taken from the GPTO is used. The GPTO data base contains all filings with the GPTO since 1979 and, further, all EPO patents, which are valid in Germany (with a one-year lag caused by priority). Patent data is used with a three-year lag to serve as an instrument for patent activities in the 1998-2000 period.

The resulting sample consists of 626 observations of manufacturing firms in Germany. All firms conduct R\&D in the year 2000 and are product innovators. $60 \%$ of the firms also conduct process innovations. Table 1 shows descriptive statistics of the variables used in this paper.

\subsection{Patenting, Secrecy and Firm Characteristics}

More than half of the firms use patents (56\%) to protect their IP. A somewhat larger part of the firms uses secrecy (61\%).7 The drawback of firm level data is that it is impossible to distinguish what exactly is protected by patents and what is protected by secrecy. Theoretical models focus on the invention level and are thus able to tackle the question which IP tool is most suitable for a particular invention. However, empirical research on the firm level cannot tell, whether patents and secrecy are used for one or more particular inventions, but focus on the use of patents and secrecy by firms in general. $41 \%$ of the sample firms employed patents and secrecy. $24 \%$ use neither patents nor secrecy. The fact that firms tend to bundle different IP protection tools is found in previous studies (e.g. Levin et al., 1987). This creates a blind spot for empirical research on the firm level, because there are many ways to combine different IP protection tools possible (Arundel, 2001). A prominent scenario is that patents tend to be used for the protection of product inventions, which are more likely to become re-engineered than process inventions, while secrecy is preferably applied to protect process inventions (Levin et al. 1987, Cohen et al. 2000). Cohen et al. (2000) highlight different situations, in which a combined use of IP protection tools is possible, even for a single invention. For example, different elements of a particular

\footnotetext{
${ }^{7}$ This percentage of secrecy users may seem to underestimate the use of secrecy, considering the fact that, in principle, every invention is kept secret in the very first phase of the innovative process. On the other hand, the question, if the firms have applied secrecy as a choice from a number of IP protection tools, is very likely to address those firms that applied secrecy consciously to protect their IP. The similar percentage of firms that applied patents and those, who used secrecy, supports this argument.
} 
Table 1: Descriptive Statistics

\begin{tabular}{lcrr}
\hline \hline variable & unit & mean & std. dev. \\
\hline patent & {$[0 / 1]$} & 0.56 & 0.50 \\
secrecy & {$[0 / 1]$} & 0.61 & 0.49 \\
sales new products & thsd. $€$ & 18.06 & 124.54 \\
$\quad$ if $>0$ (437 obs.) & thsd. $€$ & 25.93 & 148.59 \\
employment & persons & 644.74 & $3,494.48$ \\
R\&D expenditure & thsd. $€$ & 8.93 & 83.44 \\
R\&D intensity & $\in$ per emp. & 9.83 & 15.73 \\
non-R\&D innovation exp. & thsd. $€$ & 2.55 & 35.31 \\
patstock 1997 & patents per emp. & 0.04 & 0.15 \\
$\quad$ if $>0$ (337 obs.) & patents per emp & 0.07 & 0.19 \\
East Germany & {$[0 / 1]$} & 0.33 & 0.47 \\
HHI/1000 & & 0.06 & 0.08 \\
\hline number of obs. & & \multicolumn{3}{c}{626} \\
\hline \hline
\end{tabular}

invention may be protected by more than one protection tool, a strategy that is widespread in the chemicals industry (Arora, 1997). Moreover, different IP protection tools may be used at different stages of the innovative process. For example, secrecy may be applied in early states of the innovative process and patents may be used to protect the invention when it is going to be commercialized. After the invention has entered the market, however, patents and secrecy are mutually exclusive for a particular invention because of the patentings' disclosure requirement. Anyway, the jigsaw character of the different possible combinations of protection tools limits the range of possible insights of a firm level analysis.

In order to estimate the success of the differently protected inventions in the market, the sales figure of new products is used as endogenous variable. The MIP asked the firms to announce their cumulative sales with new products in the past three years, i.e. 1998-2000. On average, the sample firms' new products had sales of about $18,000 €$, which corresponds to $12 \%$ of their total sales. The censoring of firms without sales with new products, is about $30 \%$. Excluding them, the average sales with new products is higher with about $26,000 €$, equaling $17 \%$ of their total sales. To eliminate size effects, the logarithm of sales with new products is used in the analysis 8

\footnotetext{
${ }^{8}$ In order to measure the success of process innovation, which is not captured by the sales figure of new products, I employed a set of endogenous variables of cost reduction
} 
It would be desirable to have panel data on the sales figure of new products to take into account a possibly larger lag between IP protection and the commercialization of the invention. Unfortunately, the MIP is a highly unbalanced panel, so only a small share of the sampled firms responded in later years again.

An important regressor is the firms' $R \& D$ expenditure, presumably the most important input factor for innovation production. In the current sample with about one third of SMEs, an average sample firm spends 8,930 $€$ on R\&D activities. The $R \& D$ intensity is calculated as $R \& D$ expenditure in terms of employment and is used for regression instead of the $R \& D$ level variable, since, on the one hand, R\&D expenditure is highly correlated with firm size. On the other hand, R\&D intensity reflects the relative importance of innovative activities to the respective firm. Firm size effects are taken separately into account by considering the total number of employees. Company size is in so far another important variable as that larger companies not only have the capability to conduct more $R \& D$ than smaller companies, but also have a better organizational structures and suffer less financial restraints. Larger firms, therefore, are more likely to use IP protection tools and to have higher sales with new products than small firms. An average sample firm has 645 employees. As the distribution of firm size shows a considerable skewness, the logarithm of employment is used in the regression.

A further important regressor is the non-R\&D innovation expenditure. Containing every innovation expenditure, which is not $R \& D$, this variable covers marketing costs as well as further costs associated with the market entry of a product. Again, the logarithm of the variable is used to take the skewness of the distribution into account.

In the empirical section, one econometric approach requires to have an instrumental variable that is highly correlated with the current patent activity, but has no impact on the sales with new products. Firms' patent stock calculated on the basis of the GPTO data base turns out to fulfil these conditions:

$$
\text { patstock }_{i, t}=\text { patstock }_{i, t-1}(1-\delta)+\text { patent applications }_{i, t},
$$

where $\delta$ is a constant depreciation rate of knowledge which is set to 0.15 as common in the literature (see e.g. Hall, 1990, and Griliches and Mairesse, 1984). The patent stock is used with a three-years lag as an appropriate instrumental variable for patent activities in 1998-2000. To take the skewness

(percentage of total sales, dummy variable, and absolute value). However, there was no effect of the different IP protection tools. 
of the distribution into account, the patent stock is measured in terms of employment. Furthermore, the logarithm is used. Zero values are set to the sample minimum. An average firm in the current sample has a patents stock of 0.04 patents per employee. Ignoring the 290 firms without any patent, the average patent stock is slightly larger with 0.07 patents per employee.

Furthermore, firm location is taken into account using a dummy variable that takes the value one for firms located in Eastern Germany and zero for firms in Western Germany. Eastern Germany was a planned economy until 1989. The transition process into a market economy is still ongoing. Firms in Eastern Germany are found to be still less innovative and less productive than their Western German counterparts (Czarnitzki, 2004). In the current sample, one third of the firms is located in Eastern Germany.

Moreover, the Hirschman-Herfindahl Index (HHI) is used to control for intraindustry competition. The HHI represents the domestic seller concentration on the 3-digit NACE industry level. In the econometric model, the HHI is lagged by three years to avoid simultaneity problems and is divided by 1,000 to get model coefficients in one range. Industry effects measured by fourteen dummies turned out not to be statistically significant having controlled for firm size, R\&D intensity, and innovation strategies. Thus, they are not further taken into account.

\subsection{Innovation Strategies}

Innovation strategies are an important issue if focusing on firms' innovative output. If a firm's innovation activity targets at gaining market power or competitiveness advantages, its sales with new products are likely to be high, because the firm is in fierce competition and inventions must cope with high technological standards. Another firm may innovate to improve internal processes and make them more efficient. This innovation strategy is likely to have affect rather the sales figure of new products in future years.

Different innovation strategies are identified by the effects of the firm's innovations in 1998-2000. Firms scored given options on a 4-point likkert scale, where "3" corresponds to a high effect of their innovations on the respective task and " 0 " indicates that there had been no effect on that task at all. The possible effects of inventions are separated into three groups. The first group is related to innovations' effects on products and services:

- diversification of products or service offers (mean:2.31/std.dev.:0.78)

- entry into new markets or enlargement of market share $(2.12 / 0.80)$ 
- quality improvement of products or services (2.26/0.79).

The second group of effects targets process and procedure related effects of innovations:

- enlargement of product flexibility $(1.61 / 1.10)$

- enlargement of capability (1.73/1.05)

- decrease in personal costs $(1.48 / 1.04)$

- decrease in material and energy costs (1.24/0.98).

The third group describes further effects of innovations:

- improvement of environmental and health conditions $(1.17 / 1.04)$

- achievement of regulatory and standard conditions (1.24/1.08).

It turns out that the sample firm are most interested in new markets, larger market shares as well as in quality improvements of their products and services.

To detect innovation strategies underlying the effects of firm innovations, standard factor analysis is conducted. Factor analysis allows to reduce the dimensionality of the survey questions above by bundling the underlying information according to variance analysis. Table 2 shows the result.

Table 2: Effects of Innovation and Innovation Strategies

factor loading matrix (varimax rotation)

\begin{tabular}{lccc}
\hline \hline \multicolumn{1}{c}{ product related effects: } & factor 1 & factor 2 & factor 3 \\
\hline broader range of products/services & 0.10 & 0.02 & 0.50 \\
new markets/ larger market share & 0.15 & 0.08 & 0.51 \\
quality improvements of prod./serv. & 0.28 & 0.28 & 0.17 \\
$\quad$ process related effects: & & & \\
higher product flexibility & 0.71 & 0.16 & 0.10 \\
larger capability & 0.77 & 0.17 & 0.04 \\
lower personal costs & 0.78 & 0.13 & 0.06 \\
lower material and energy costs & 0.62 & 0.32 & 0.08 \\
$\quad$ other effects: & & & \\
improved environmental/health conditions & 0.29 & 0.64 & 0.02 \\
achieved regulatory/standard conditions & 0.23 & 0.61 & 0.06 \\
\hline \hline
\end{tabular}

It turns out that three dimensions capture most of the variance in the scorings, corresponding to the three groups of innovations' effects defined in the survey. The first factor is highly correlated with the second group, the process improvement related effects of innovations. Innovation activities aiming 
at a higher product flexibility, at a larger capability, as well as at lower personal, material, and energy costs can be interpreted as an internal or process improvement strategy for innovating. The second dimension captures the third group of innovations' effects. Firms conduct innovation projects to comply with environmental and health conditions as well as with regulatory and standard conditions. Those firms follow a compliance strategy for innovating. The third dimension shows a correlation between diversification of products or service offers and entry into new markets or enlargement of market share the innovations led to. Those firms are innovative to get market power or improve their recent position in the market. For the following analysis, let's call it a new markets strategy for innovating.

The different innovation strategies are supposed to have an impact on firms' innovative success in the market. Firms that develop innovations to enlarge their market share and to broaden their product pallet are supposed to have higher sales with new products than firms, who innovate to lower their production costs. Three score variables corresponding to the estimated factors are included in further regressions to take into account the different innovation strategies.

Furthermore, 'industry strategies' are focused on to account for sectoral heterogeneity. In some industries, like in basic metals, inventions often base on relatively general principles of mechanical engineering and will therefore not be patented, whereas in other industries, like in pharmaceutics, chemistry, or high-technology industries, IP protection is supposed to be more important (Arundel, 2001). The fraction of firms that applied patents and secrecy on the 3-digit NACE level is taken into account to control for industry strategies.

\section{Empirical Analysis}

The empirical part of the paper analyzes whether patents and secrecy have a positive impact on firms' sales figures of new products to address the question, whether patents or secrecy are more important to protect inventions in their market phases. Endogenous variable is the logarithm of sales with new products. The most important regressors are two dummy variables, one controls for patenting, the second for application of secrecy. Tobit and instrumental variable (IV) regression is used. Table 3 shows the estimation results.

The first column shows the tobit estimates. It turns out that there is a positive, statistically significant relationship between patenting and sales with 
Table 3: Success of Firms' Innovation in the Market endogenous variable: $\log ($ sales with new products)

\begin{tabular}{|c|c|c|}
\hline & tobit & IV regression ${ }^{A}$ \\
\hline & $\begin{array}{c}\text { coef. } \\
(\text { t-stat })^{B}\end{array}$ & $\begin{array}{c}\text { coef. } \\
(\text { t-stat })^{B}\end{array}$ \\
\hline patent & $\begin{array}{l}1.28^{* * *} \\
(3.18)\end{array}$ & $\begin{array}{c}0.48^{*} \\
(1.65)\end{array}$ \\
\hline secrecy & $\begin{array}{c}0.49 \\
(1.22)\end{array}$ & $\begin{array}{c}0.41 \\
(1.03)\end{array}$ \\
\hline process strategy & $\begin{array}{c}0.12 \\
(0.56)\end{array}$ & $\begin{array}{c}0.12 \\
(0.56)\end{array}$ \\
\hline compliance strategy & $\begin{array}{r}0.25^{*} \\
(0.95)\end{array}$ & $\begin{array}{c}0.26 \\
(0.69)\end{array}$ \\
\hline new markets strategy & $\begin{array}{c}0.60^{*} \\
(1.41)\end{array}$ & $\begin{array}{c}0.58 \\
(1.35)\end{array}$ \\
\hline $\log ($ employment $)$ & $\begin{array}{l}0.35^{* *} \\
(2.04)\end{array}$ & $\begin{array}{c}0.28 \\
(1.39)\end{array}$ \\
\hline R\&D intensity & $\begin{array}{l}0.03^{* * *} \\
(2.91)\end{array}$ & $\begin{array}{l}0.03^{* *} \\
(2.37)\end{array}$ \\
\hline $\log ($ non $R \& D$ inno. exp.) & $\begin{array}{c}0.14 \\
(1.36)\end{array}$ & $\begin{array}{c}0.17 \\
(1.61)\end{array}$ \\
\hline East Germany & $\begin{array}{l}-1.24^{* * *} \\
(-3.10)\end{array}$ & $\begin{array}{l}-1.19^{* * *} \\
(-2.58)\end{array}$ \\
\hline $\mathrm{HHI}$ & $\begin{array}{l}-1.38 \\
(-0.61)\end{array}$ & $\begin{array}{l}-1.26 \\
(-0.56)\end{array}$ \\
\hline constant & $\begin{array}{l}-3.81^{* * *} \\
(-3.76)\end{array}$ & $\begin{array}{l}-2.76^{* * *} \\
(-2.29)\end{array}$ \\
\hline $\begin{array}{l}\text { number of obs. } \\
\text { censoring }\end{array}$ & $\begin{array}{c}626 \\
30 \%\end{array}$ & $\begin{array}{c}626 \\
30 \%\end{array}$ \\
\hline Log-Likelihood & $-1,452.76$ & $-1,437.96$ \\
\hline
\end{tabular}


new products whereas there is no effect for secrecy. The coefficient of secrecy is much smaller than the patent coefficient and the t-statistic is fairly low. These findings are in line with the hypothesis that patenting indicates valuable invention, although a shift in importance to a more strategic use of patents took place. Among product innovating firms, patents are more effective to protect inventions in the market than secrecy. Further, the significant effect of patenting may provide a hint that patent protection is used to secure monopoly profits, where they are large. Secrecy seems to play no role at all among product innovating firms in the inventions' market phase. How does this fit a $61 \%$ share of sample firms that applied secrecy? One explanation is that firms use secrecy to protect their inventions in early phases of the innovative process, e.g. where the research outcome is still unclear, rather than once the inventions have entered the market. A leaded endogenous variable, which is, unfortunately, not available to me, could take these early-state inventions into account. Another explanation might be that firms use secrecy to protect their process inventions. Remember that $60 \%$ of the sample firms also conduct process innovations, whose success is not captured by the sales figure of new products. Including a dummy variable for process innovating firms does not change the results and the estimated coefficient is not statistically significant.

Looking at firms' innovation strategies, it turns out that there is no impact of a strategy that aims at improving internal processes, enlarging capabilities and lowering costs of internal processes (process strategy). Such a strategy rather creates a positive environment for later innovation activities than raising current sales with new products. An innovation strategy aiming at compliance with regulatory, health or environmental conditions (compliance strategy), however, increases sales with new products. Innovations in that context may be such that cope with new legal environmental conditions that may concern a whole industry, e.g. in the motor vehicle industry. An early inventor may easily profit from such an invention. Firms following a new markets strategy of innovation aiming at enlarging the market share or at the entrance into new markets turn out to have significant larger sales with new products than other firms. Those firms are likely to be high-technology firms in a fierce competition and their products have to cope with high technological standards. The presumably high quality of those inventions is mirrored by sales with new products.

It, further, turns out that firm size mapping the capability of firms to conduct $R \& D$ as well as R\&D intensity, which measures the importance of R\&D to the respective firm, have a positive impact on sales with new products. Non- 
R\&D innovation expenditure has no significant impact on sales with new products.

Eastern German firms turn out to have significant smaller sales with new products than their Western German counterparts. Innovative activity of Eastern German firms leads rather to a catching up with the recent standards than to releasing products that are new to the market. Moreover, there is no effect of intra-industry competition measured by the HirschmanHerfindahl Index (HHI) $!^{9}$

The first econometric specification ignores that patenting may depend on the further regressors, e.g. on firms size and R\&D intensity. This might have driven the positive result for patenting in the previous regression. IV regression is applied as an alternative econometric specification to take suspected endogeneity of patent activities into account and check for robustness of the positive result for patenting. In a first step, a probit regression on the patent dummy is conducted to take the effects of the further variables into account. The second step repeats the tobit estimation with the estimated patent propensity included instead of the patent dummy.

When applying IV estimation, it is important to have at least one appropriate instrumental variable to identify the first step regression. Such an instrumental variable has to provide a significant correlation with the decision to patent and must further not be fully or approximately fully explained by the regressors in the outcome equation. I use the firms' patent stock in the year 1997 as instrumental variable. The lagged patent stock has a significant impact on current patent activities, but there is no statistically significant effect on sales with new products. The same holds for the fractions of firms in an industry using patents and secrecy. Those variables serve as further instruments.

Table 4 shows the results of the first step probit regression. It turns out that the lagged patent stock has a positive impact on the patent propensity. Firms apparently commit themselves to patenting. The persistence in patent application shows that patents are an appropriate instrument for IP protection or for strategic issues or both from the patent holders' view.

It further turns out that there is a strong correlation between the patent propensity and the use of secrecy. Firms tend to apply both IP protection instruments. This confirms the common finding of previous studies that firms

\footnotetext{
${ }^{9}$ An LR-test showed that fourteen industry dummies that had been included in an alternative specification are not statistically significant.
} 
Table 4: First Step of the IV Regression: Probit Model endogenous variable: patent dummy

\begin{tabular}{lcc}
\hline \hline & coef. & t-stat $^{A}$ \\
\hline $\log ($ patent stock 1997$)$ & $0.14^{* * *}$ & 6.74 \\
secrecy & $0.62^{* * *}$ & 4.17 \\
fraction of patent users in industry & $11.18^{* * *}$ & 6.03 \\
fraction of secrecy users in industry & -5.32 & -2.63 \\
process strategy & -0.01 & -0.07 \\
compliance strategy & -0.09 & -0.61 \\
new markets strategy & 0.09 & 0.64 \\
log(employees) & $0.27^{* * *}$ & 5.20 \\
R\&D intensity & 0.01 & 1.44 \\
HHI & -0.32 & -0.44 \\
East Germany & -0.33 & -2.35 \\
constant & -1.14 & -3.02 \\
\hline number of obs. & 626 \\
Pseudo- ${ }^{2}$ & 0.31 \\
Log-Likelihood & -294.67 \\
\hline \hline$* * *(* * *)$ indicate a significance level of 1\% (5\%, 10\%). \\
${ }^{A}$ The t-statistics are based base on bootstrapped standard errors. \\
200 replications are used on the whole estimation procedure.
\end{tabular}

tend to bundle different IP protection tools (Levin et al., 1987, Cohen et al., 2000, König and Licht, 1995, and Arundel et al., 1995). Following Cohen et al. (2000) and Arora (1997) there are many situations in which patents and secrecy may be applied for one particular invention. Different IP protection tools may be used to protect the invention in different development phases, e.g. secrecy in the pre-market phase and a patent afterwards. Moreover, an invention may be split in its single elements and both protection tools may be applied for the particular elements. Focusing on the firm level, there are even more situations in which firms may apply both instruments. For example if a firm conducts product and process research, which holds for about $60 \%$ of the sample firms, they may prefer secrecy for their process inventions and patents for their product inventions to prevent them from becoming reengineered.

The fraction of firms in an industry that uses patents measured on the 3digit NACE level shows the largest effect on the decision to patent. For the 
fraction of secrecy users, there is no effect. These variables capture industry heterogeneity. The fact that patents' importance varies across industries is unanimously found by previous studies. In some industries, like basic metals, inventions tend to be based on general engineering principles, that are not patentable. Whereas in high-technology industries as well as in chemistry and the pharmaceutical industry patents are supposed to be much more important.

Innovation strategies on the firm level turn out to have no effect on the patent decision.

Moreover, firm size has a positive impact on the patent probability, because larger firms usually conduct more $\mathrm{R} \& \mathrm{D}$, what enables them to file more patents. In addition, large firm may have an own legal department and may not suffer financial constraints to the same degree as small firms. This is of great value in the case of infringement as potential infringement costs constitute a significant barrier to patent. R\&D intensity as a measure of the importance of innovative activity to the firm turns out to have no impact on the patent propensity. This finding contrasts, on the one hand, the finding confirms the result by Arundel et al. (1995) that R\&D intensity is not correlated with the IP protection propensity. They interpret the result that size effects are more important than R\&D intensity by the organizational structure of the firms' innovation activities, which is supposed to by determined by size effects rather than by the $R \& D$ expenditure relative to firm size. Having controlled for industry preference and firm size, there is, further, no effect for firms located in Eastern German and the concentration index (HHI).

The second column of Table 3 shows the estimation results of the IV regression. Instead of the patent dummy, the estimated patent propensity of the probit model is used as a regressor. Patenting, again, has a significant impact on sales with new products. The positive result of patenting is therefore approved if endogeneity of the patent activity is taken into account. The further regressors loose in significance, because their influence on the patent decision is already taken into account in the first step probit estimation. R\&D intensity is a significant factor in this model showing that sales with new products increase with the importance of $R \& D$. The positive effect is in line with Arundel et al. (1995), who find that R\&D intensity is positively correlated with the importance of product patents. Moreover, the dummy variable for Eastern German firms is still significant.

The empirical results confirm previous findings, e.g. regarding the tendency of firms to bundle different IP protection tools or the relationship between 
patents, firm size, and R\&D intensity for product innovators.

In contrast to prior studies that measure the effectiveness of different IP tools by the firms' valuation of that tools, this paper focus on the success of the inventions in the market, measured by sales figure of new products. It turns out that there is a strong positive correlation between patenting activities of the firms and market success of their inventions, whereas there is no effect for secrecy at all. This finding is robust if controlled for endogeneity of patenting. This finding is in line with the hypothesis that patenting indicates valuable inventions, although a shift in importance to a more strategic use of patents took place in the past. Patents thus are interpreted to be the more effective tool to protect inventions in the market than secrecy. Furthermore, the significant effect of patenting might provide a hint that patent protection is used to secure monopoly profits, where they are large. Secrecy seems to play no role at all among product innovating firms to protect a profitable invention in the market phase.

As the previous regressions cannot ultimately rule out the argument that patenting may have been strategically motivated in the first place, further evidence for the hypothesis that patents are the superior instrument for IP protection among product innovating firms is provided. The MIP questionnaire contains a question on the importance of the applied IP protection tools. Those firms, who actually applied the particular tool, scored its importance on a 3-point likkert scale, where 3 corresponds to "very important" and one corresponds to "not important".

Figure 2 shows the average importance of patents and secrecy for the sample firms for different firm groups with respect to their sales figure of new products. The table below gives information on the numbers of observations and the shares of respondents for each group. It becomes obvious that German firms tend to find both IP tools important - the average importance of patents and secrecy is always between "2" (little important) and "3" (very important) -, which approves the result of Arundel et al. (1995). It turns out clearly that patents are scored to be more important than secrecy in every group. The gap between the average importance of patents and secrecy is larger for firms with small shares of sales with new products. Those firms are supposed to be the smaller firms, which might lack the capability to transfer an invention into a new product. However, also firms with large shares of new products, score patents to be on average more effective for IP protection as opposed to secrecy.

Thus, this study concludes that patents are more effective for IP protection among product innovating firms, which is approved by the firms' point of view. 
Figure 2: Effectiveness of Patents and Secrecy for IP Protection

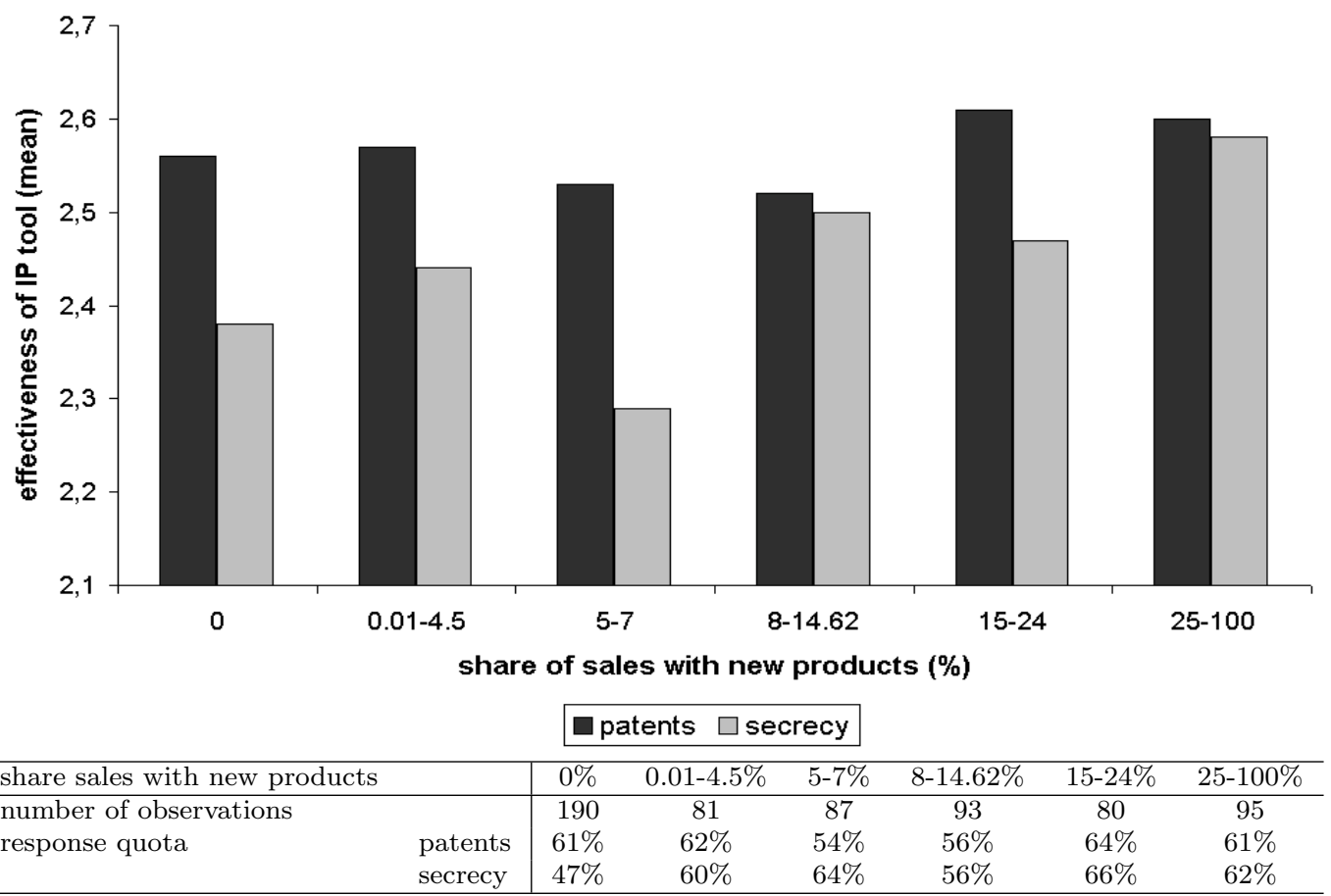

\section{Conclusions}

In the 1990s, patenting schemes changed in many respects: technological and institutional conditions altered, upcoming new technologies accelerated the shift from price competition towards competition based on technological inventions, and strategic patenting became important. At the same time, a worldwide surge in patenting took place. These developments raise the question whether patents are still used to protect valuable inventions or if they rather indicate strategic firm behavior, while alternative methods are used for the protection of intellectual property (IP).

Patents are legal instruments to protect IP by granting the patent holder a temporary monopoly position including the right to sue for infringement. However, patents bear the disadvantage that the patenting firms have to disclosure the patented technology. This leads some firms to prefer secrecy as a mutually exclusive IP protection tool.

In the early 1990s, empirical research found secrecy to be more effective for IP protection than patents from the firms' point of view. These studies use the firms' evaluation of the different IP tools to measure their importance. 
This study introduces a new measure of the importance of patents as opposed to secrecy for product innovating firms focusing on the inventions' success in the market, where patents and secrecy are mutually exclusive due to the disclosure requirement of patenting. Inventions' market success is measured by the sales figure of new products.

Focusing on product innovating firms in German manufacturing in 2000, after significant changes in patenting schemes have taken place, a strong positive correlation between patents and sales with new products turns out, whereas there is no effect for secrecy. This finding is in line with the hypothesis that patents are still used to protect valuable invention, although the patents' importance as a strategic tool has significantly gained in importance. Moreover, patents turn out to be the more effective tool to protect inventions in the market phase as opposed to secrecy, which is also applied by a large fraction of the sampled firms. This result may indicate that patent protection is used to secure monopoly profits, where they are large. Secrecy, however, may be rather applied for early-state inventions that will enter the market in a later period. Another explanation might be that firms use secrecy to protect their process inventions, which is not captured by the sales figure of new products. However, additional survey evidence is provided that patents are more effective as opposed to secrecy from the firms' point of view.

For further research on the importance of patents and secrecy, data on the invention level would be desirable. 


\section{References}

Anton, J.J. and D.A. Yao (2004), Little Patents and Big Secrets: Managing Intellectual Property, RAND Journal of Economics 35, 1-22.

Arora (1997), Patents, Licensing, and the Market Structure in Chemicals, Research Policy 26, 391-403.

Arundel, A. (2001), The Relative Effectiveness of Patents and Secrecy for Appropriation, Research Policy 30, 611-24.

Arundel, A., G. van de Paal and L. Soete (1995), Innovation Strategies of Europe's Largest Industrial Firms, MERIT, Maastricht.

Cohen W.M., R.R. Nelson, and J.P. Walsh (2000), Protecting Their Intellectual Assets: Appropriability Conditions and Why U.S. Manufacturing Firms Patent (or Not), NBER Working Paper no. 7552.

Czarnitzki, D. (2004), The Extent and Evolution of the Productivity Deficiency in Eastern Germany, Journal of Productivity Analysis, forthcoming.

Denicolò, V. (1996), Patent Races and Optimal Patent Breadth and Length, Journal of Industrial Economics 44, 249-65.

Friedman, D.D., W.M. Landes, and R.A. Posner (1991), Some Economics of Trade Secret Law, Journal of Economic Perspectives 5, 61-72.

Griliches, Z. and J. Mairesse (1984), Productivity and R\&D at the Firm Level, in: Griliches Z. (ed.), R\&D, Patents and Productivity, Chicago, $339-74$.

Hanel, P. (2002), The Use of Intellectual Property Rights and Innovation by Manufacturing Firms in Canada, mimeo.

Hall, B.H. (1990), The Manufacturing Sector Master File: 1959-1987, NBER Working Paper no. 3366.

Hall, B.H. and R.M. Ham (2001), The Patent Paradox Revisited: Determinants of Patenting in the US Semiconductor Industry, 1979-1995, RAND Journal of Economics 32, 101-28.

Horstman, I., G.M. MacDonald, and A. Slivinski (1985), Patents as Information Transfer Mechanism: To Patent or (Maybe) Not to Patent, Journal of Political Economy 93, 837-58. 
Kortum, S. and J. Lerner (1999), What is Behind the Recent Surge in Patenting?, Research Policy 28, 1-22.

König, H. and G. Licht (1995), Patents, R\&D, and Innovation, ifo Studien Zeitschrift für empirische Wirtschaftsforschung 4/95, 521-43.

Langinier, C. and G. Moschini (2002), The Economics of Patents: An Overview, Working Paper 02-WP, Center for Agricultural and Rural Development, Department of Economics, Iowa State University.

Levin, R.C., A.K. Klevorick, R.R. Nelson, and S.G. Winter (1987), Appropriating the Returns from Industrial Research and Development, Brooking Papers on Economic Activity 3, 783-831.

Mansfield, E. (1986), Patents and Innovation: An Empirical Study, Management Science 32, 173-81.

Nordhaus (1969), Invention, Growth, and Welfare, Cambridge MA, MIT Press.

Nordhaus (1972), The Optimum Life of a Patent: Reply, American Economic Review 62, 428-31.

Scotchmer, S. (1991), Standing on the Shoulder of Giants: Cumulative Research and the Patent Law, Journal of Economic Perspectives 5, $29-41$.

Scotchmer, S. (2004), Innovation and Incentives, MIT Press, Cambridge MA, forthcoming.

Shapiro, C. (2001), Navigating the Patent Thicket: Cross Licenses, Patent Pools, and Standard Setting, in Jaffee, A.B., J. Lerner, and S. Stern (eds.), Innovation Policy and the Economy Vol. 1, MIT Press, Cambridge MA, 119-50.

Tandon, P. (1982), Optimal Patents with Compulsory Licensing, Journal of Political Economy 90, 470-86. 